\title{
Effect of polyethylene glycol 4000 supplementation on the performance of yearling male Pedi goats fed dietary mixture levels of Acacia karroo leaf meal and Setaria verticillata grass hay
}

\author{
David Brown ${ }^{1}$ - Jones W. Ng'ambi ${ }^{1}$
}

Received: 4 October 2016 / Accepted: 26 April 2017 /Published online: 9 May 2017

(C) The Author(s) 2017. This article is an open access publication

\begin{abstract}
Eighteen yearling male Pedi goats weighing $21.7 \pm 3.1 \mathrm{~kg}$ were used in a 42-day trial in a 2 (Acacia karroo leaf meal levels) $\times 3$ (levels of PEG 4000) factorial arrangement in a completely randomized design to determine PEG 4000 supplementation levels for optimal productivity of indigenous Pedi goats fed different mixture levels of $A$. karroo leaf meal and Setaria verticillata (L.) P.Beauv. grass hay. Each goat was supplemented with 0,23 or $30 \mathrm{~g}$ of PEG 4000 per day in addition to dietary mixture of $A$. karroo and $S$. verticillata hay. Polyethylene glycol 4000 supplementation had no effect $(P>0.05)$ on nutrient intake of goats. However, a diet $\times$ PEG $(P<0.05)$ was observed for intake of all nutrients studied. Dry matter, OM, NDF and ADF intakes per goat were optimized at PEG 4000 supplementation levels of 19.62, 19.62, 19.61 and $19.53 \mathrm{~g} /$ goat/day, respectively, for diets containing $20 \%$ A. karroo leaf meal. Polyethylene glycol 4000 supplementation had no effect $(P>0.05)$ on the apparent digestibility of all nutrients. The dietary inclusion level of $A$. karroo leaf meal at $20 \%$ improved $(P<0.05)$ $\mathrm{DM}, \mathrm{OM}, \mathrm{CP}, \mathrm{NDF}$ and ADF digestibility of goats. Crude protein digestibility was optimized at a PEG 4000 supplementation level of $15.78 \mathrm{~g} / \mathrm{goat} /$ day. Dietary mixture level and PEG 4000 supplementation had no effect $(P>0.05)$ on final weights of Pedi goats. Similar results were observed for blood urea and glucose concentrations of yearling male Pedi goats. However, daily body weight gain was higher $(P<0.05)$ in goats fed $50 \%$ A. karroo leaf meal than those on $20 \%$
\end{abstract}

David Brown

db4010396@gmail.com

1 Department of Agricultural Economics and Animal Production, Faculty of Science and Agriculture, University of Limpopo, Private Bag X1106, Sovenga, South Africa inclusion level. Polyethylene glycol 4000 has potential to improve the feeding value of tanninifeorus A. karroo leaf meal.

Keywords Acacia karroo · Tannins · Polyethylene glycol · Goat

\section{Introduction}

Goat production contributes immensely to the economy and food security of many smallholder farmers, particularly in the rural areas (Ngambi et al. 2013). Indigenous Pedi goats are important domestic animals in Limpopo Province of South Africa. The breed derived its name from the Bapedi people in the north of the country (Dagris 2007). Pedi goats have small to medium frame with short horns. Coat colour varies from uniform brown to white with a variety of black and white patterns (Snyman 2014). They provide immediate benefits in the form of milk and meat, hide and skins and cash to the poor in the communal areas of South Africa (Ngambi et al. 2013). However, their productivity is constrained by a shortage of good quality feed, especially during the long dry season (Matlebyane et al. 2010). Available fodder during this period is fibrous and low in protein. Poor nutrition results in poor productivity. Undernourished animals are also predisposed to diseases and parasites and may die in extreme cases (Matlebyane et al. 2010).

Browse plants have the potential to alleviate feed shortages and nutritional deficiencies experienced during the critical dry period of the year (Belachew et al. 2013). Indigenous legume trees such as Colophospermum mopane, Brachystegia spiciformis and Acacia genus are gaining importance as protein sources for livestock during the dry season (Dube 2000; Mapiye et al. 2011). Of particular interest to animal nutritionists in Southern Africa is Acacia karroo Hayne. A. karroo is widely spread and abundantly available during the dry season (Brown 
et al. 2016). The foliage contains high concentrations of crude protein (100-250 g/kg DM) and minerals (Mokoboki et al. 2005) and has the potential to increase productivity of goats feeding on low-quality roughages. However, their use as protein supplement is restricted by the presence of tannins in their foliage. According to Mokoboki et al. (2005), A. karroo contained $80.7 \mathrm{~g} / \mathrm{kg}$ DM extracted condensed tannins (CT). At a level above $50 \mathrm{~g} / \mathrm{kg}$ DM, CT restricts nutrient utilization and digestibility and may bind to digestive enzymes, thus reducing their activities (Christopher 2012). Recommendations on the use of A. karroo are complicated due to the presence of CT in the plant. A. karroo leaf meal inclusion levels of 20 and $50 \%$ were used in the present study. These inclusions include low and high levels as indicated in the literature (Brown et al. 2016, 2017).

Tannin-binding agents such as polyethylene glycol (PEG) offer a viable technique to enhance the nutritive value of tannin-rich trees and shrubs (Singh et al. 2005; Nsahlai et al. 2011). Polyethylene glycol is an inert unabsorbed molecule that can form stable complexes with tannins, preventing the binding between tannins and proteins and can even displace protein from a pre-formed tannin-protein complex (Makkar 2003; Frutos et al. 2004). Polyethylene glycol 4000 has been used to alleviate negative effects of CT, consequently improving the performance of animals on tanniniferous-based diets (Decandia et al. 2000; Motubatse et al. 2008). However, other authors have found that PEG 4000 supplementation does not improve the performance of animals on tannin-rich diets (Barry et al. 2001; Bhatta et al. 2002). Responses to PEG 4000 supplementation may depend on the acacia species (amount and type of tannins present) and animal breed (Motubatse et al. 2008). In previous experiments, PEG levels of 0,23 or $30 \mathrm{~g}$ were used to alleviate the effects of tannins in ruminants (Silanikove et al. 1996a, b; Motubatse et al. 2008). It is, therefore, important to ascertain the effects of PEG 4000 on the performance of indigenous Pedi goat breeds fed on diets supplemented with tanniniferous A. karroo leaf meal.

The objective of this study was, therefore, to determine PEG 4000 supplementation levels for optimal productivity of indigenous Pedi goats fed different mixture diets of $A$. karroo leaf meal and Setaria verticillata (L.) P.Beauv. grass hay. It was hypothesized that PEG 4000 supplementation levels do not have effect on the optimal productivity of indigenous Pedi goats fed different mixture diets of $A$. karroo leaf meal and $S$. verticillata (L.) P.Beauv. grass hay.

\section{Materials and methods}

\section{Study site}

The study was conducted at the University of Limpopo Experimental farm, South Africa (latitude $27.55^{\circ} \mathrm{S}$ and longitude $24.77^{\circ} \mathrm{E}$ ) in October 2014. The ambient temperatures at the study site range between 20 and $36{ }^{\circ} \mathrm{C}$ during summer and between 5 and $25^{\circ} \mathrm{C}$ during winter. Mean annual rainfall is $446.8 \mathrm{~mm}$ with the dry season occurring between April and October and the rainy season occurring between November and March.

\section{Collection, drying and storage of plant material}

A. karroo leaves were harvested during the winter months (June-August). Branches of each shrub were removed manually and placed in a shed. Leaves were allowed to air dry on the branches and then removed by carefully beating the branches with sticks. The leaves were stored in air-tight bags until feeding time. S. verticillata (L.) P.Beauv. is a perennial grass belonging to the tribe Paniceae and is widely grown by commercial farmers in Limpopo Province of South Africa. The grass is well grazed during summer and is suitable for hay making. Botanical authentication of the plant materials was done at the Larry Leach Herbarium, Department of Biodiversity, University of Limpopo.

\section{Animals, management, diet and experimental design}

All procedures involving animals were approved by the Animal Research Ethics Committee of the University of Limpopo, South Africa. Eighteen yearling male indigenous Pedi goats with a mean live weight of $21.7 \pm 3.1 \mathrm{~kg}$ were randomly allocated to six treatments in a 2 (A. karroo leaf meal levels) $\times 3$ (levels of PEG 4000) factorial arrangement (SAS 2010), in a completely randomized design. Each treatment had three replicates with one goat per replicate. The six treatments are given in Table 1. Yearling male Pedi goats were selected because they are the ones fattened for meat in the province. The grass and A. karroo leaves were chopped and thoroughly mixed to avoid diet selection by the animals when fed. The goats were fed ad libitum, allowing a $15 \%$ refusal of each diet, as suggested by Kaitho et al. (1996) and the experiment lasted for 42 days. The animals were housed in

Table 1 Feed composition of the experimental diets

\begin{tabular}{llll}
\hline & \multicolumn{2}{l}{ Diets } & \\
\cline { 2 - 3 } Diet code & $\begin{array}{l}\text { Acacia } \\
\text { karroo }(\%)\end{array}$ & $\begin{array}{l}\text { Setaria verticillata } \\
\text { grass }(\%)\end{array}$ & Peg (g/goat/day) \\
\hline $\mathrm{A}_{20} \mathrm{~S}_{80} \mathrm{P}_{0}$ & 20 & 80 & 0 \\
$\mathrm{~A}_{20} \mathrm{~S}_{80} \mathrm{P}_{23}$ & 20 & 80 & 23 \\
$\mathrm{~A}_{20} \mathrm{~S}_{80} \mathrm{P}_{30}$ & 20 & 80 & 30 \\
$\mathrm{~A}_{50} \mathrm{~S}_{50} \mathrm{P}_{0}$ & 50 & 50 & 0 \\
$\mathrm{~A}_{50} \mathrm{~S}_{50} \mathrm{P}_{23}$ & 50 & 50 & 23 \\
$\mathrm{~A}_{50} \mathrm{~S}_{50} \mathrm{P}_{30}$ & 50 & 50 & 30 \\
\hline
\end{tabular}


individual metabolic cages that allowed the separation of faeces and urine $\left(5.5^{\prime} \times 2.0^{\prime}\right)$ and were given the experimental diets during the study period. Feed intake was recorded on a daily basis during the collection period. Intake was calculated by subtracting leftovers from the feed given. Water was offered ad libitum. The PEG 4000 was dissolved in water (23 or $30 \mathrm{~g}$ of PEG 4000/25 $\mathrm{ml}$ of water per animal per day), and the contents were given to the animal through dosing daily at 08 h00 before morning feeding (Decandia et al. 2000). Animals not receiving PEG 4000 were dosed with $25 \mathrm{ml}$ of water. The goats were weighed three times, at the start of the experiment, on day 35 and on the 42nd day when data collection ended. Average daily gains were calculated as differences between final and initial body weights divided by number of days of feeding. The weighing of the goats was carried out before morning feeding to avoid feed effect (Sarwatt et al. 2003). During the collection period, daily output of faeces for each animal were collected, mixed and recorded. Ten percent of the faeces were sub-sampled and kept. All the subsampled faeces were pooled on animal basis, dried and kept until required for chemical analysis. Blood samples were taken from each goat via the jugular vein before the morning feeding on day 36 and on the last day of the experiment. The blood samples were collected into anticoagulant free bottles, allowed to coagulate at room temperature and centrifuged at $1500 \times \mathrm{g}$ for $10 \mathrm{~min}$. The supernatant sera were then harvested and stored at $-20{ }^{\circ} \mathrm{C}$ for subsequent biochemical analysis (Olafadehan et al. 2014).

Nutrient composition of $A$. karroo and $S$. verticillata grass are presented in Table 2. A. karroo contained $127 \mathrm{~g} \mathrm{CP} / \mathrm{kg}$ DM and $921 \mathrm{~g} \mathrm{OM} / \mathrm{kg}$ DM. It also contained phenolic compounds. S. verticillata hay contained 79,779 and $507 \mathrm{~g}$ of CP, NDF and ADF per kilogram DM, respectively. $S$. verticillata hay contained no traces of phenolic compounds.

The nutritive values of dietary mixtures of $A$. karroo and $S$. verticillata hay are presented in Table 3 . Diet containing 50\%

Table 2 Nutrient composition of Acacia karroo leaf meal and Setaria verticillata hay

\begin{tabular}{lll}
\hline Nutrient & $\begin{array}{l}\text { Acacia } \\
\text { karroo }\end{array}$ & $\begin{array}{l}\text { Setaria } \\
\text { verticillata } \\
\text { hay }\end{array}$ \\
\hline Dry matter $(\mathrm{g} / \mathrm{kg})$ & 971 & 962 \\
Organic matter $(\mathrm{g} / \mathrm{kg} \mathrm{DM})$ & 921 & 914 \\
Crude protein $(\mathrm{g} / \mathrm{kg} \mathrm{DM})$ & 127 & 79 \\
Acid detergent fibre $(\mathrm{g} / \mathrm{kg} \mathrm{DM})$ & 325 & 507 \\
Neutral detergent fibre $(\mathrm{g} / \mathrm{kg}$ & 380 & 779 \\
$\quad$ DM) & 2.0 & 0 \\
Condensed tannins $(\% \mathrm{DM})^{\mathrm{a}}$ & 1.9 & 0 \\
Total phenolics $(\% \mathrm{DM})^{\mathrm{b}}$ & & \\
\hline
\end{tabular}

${ }^{\text {a }}$ Condensed tannins as percentage DM leucocyanidin equivalent

${ }^{\mathrm{b}}$ Expressed as tannic acid equivalent (\%)
Table 3 Chemical composition of the dietary mixtures of Acacia karroo leaf meal and Setaria verticillata hay

\begin{tabular}{lll}
\hline & Diet & \\
\cline { 2 - 3 } Nutrient & $\mathrm{S}_{80} \mathrm{~A}_{20}$ & $\mathrm{~S}_{50} \mathrm{~A}_{50}$ \\
\hline Dry matter $(\mathrm{g} / \mathrm{kg})$ & 952 & 970 \\
Organic matter $(\mathrm{g} / \mathrm{kg} \mathrm{DM})$ & 915 & 917 \\
Crude protein $(\mathrm{g} / \mathrm{kg} \mathrm{DM})$ & 89 & 103 \\
Acid detergent fibre $(\mathrm{g} / \mathrm{kg} \mathrm{DM})$ & 470 & 415 \\
Neutral detergent fibre $(\mathrm{g} / \mathrm{kg} \mathrm{DM})$ & 699 & 579 \\
Condensed tannins $(\% \mathrm{DM})^{\mathrm{a}}$ & 0.4 & 1.0 \\
Total Phenolics $(\% \mathrm{DM})^{\mathrm{b}}$ & 0.3 & 0.9 \\
\hline
\end{tabular}

${ }^{\mathrm{a}}$ Condensed tannins as percentage DM leucocyanidin equivalent

${ }^{\mathrm{b}}$ Expressed as tannic acid equivalent (\%)

A. karroo leaf meal inclusion level contained $103 \mathrm{~g} \mathrm{CP} / \mathrm{kg}$ DM. The condensed tannin and total phenolic contents were 1.0 and $0.9 \%$, respectively. A diet containing $20 \%$ A. karroo leaf meal inclusion level had $89 \mathrm{~g} \mathrm{CP} / \mathrm{kg} \mathrm{DM}, 0.4 \%$ condensed tannin and $0.3 \%$ total phenolic content.

\section{Chemical analyses}

Dry matter, organic matter and crude protein were determined using the methods described by AOAC (2005). Neutral detergent fibre (NDF) and acid detergent fibre (ADF) were determined by the method of Van Soest (1994). Total phenolics were determined using Folin-Ciocalteau methods and expressed as tannic acid equivalent (\% DM) (Water and Mole 1994). Condensed tannins were determined using the Butanol-HCl method and expressed as leucocyanidin equivalent (\% DM) (Porter et al. 1986). Serum glucose was done on a 600: UniCel DxC General Chemistry Analyzer. Serum urea was obtained by the method of Valley et al. (1980).

\section{Statistical analysis}

The effects of PEG 4000 supplementation, level of A. karroo leaf meal inclusion and their interaction on intake, in vivo digestibility, growth rate and blood metabolic profiles of goats were analyzed using GLM procedures of SAS (2010). Where significant treatment effects were detected, means were separated by Fisher's least significant difference. The responses in optimal intake, digestibility and body weight change to the level of browse inclusion were modelled using the following quadratic equation:

$Y=a+b_{1} x+b_{2} x^{2}$

where $Y$ is the feed intake (g/day), digestibility (coefficient) or body weight change (g/day); $a$ is the intercept; $b_{1}$ and $b_{2}$ are the coefficients of the quadratic equation; $x$ is the level of inclusion 
and $-b_{1} / 2 b_{2}=$ level of inclusion value for optimal response. The quadratic model was used because it gave the best fit.

\section{Results}

Results of the effect of PEG 4000 supplementation, A. karroo leaf meal inclusions and their interaction on diet intake, digestibility, body weight change and blood serum chemistry of yearling male indigenous Pedi goats fed a basal diet of $S$. verticillata grass hay are presented in Table 4. Polyethylene glycol 4000 supplementation had no effect $(P>0.05)$ on nutrient intake of goats. However, the interaction effect of diet and PEG was detected $(P<0.05)$ for intake of all nutrients studied. Dry matter, OM, NDF and ADF intakes per goat were optimized at PEG 4000 supplementation levels of 19.62, $19.62,19.61$ and $19.53 \mathrm{~g} / \mathrm{goat} /$ day, respectively, for diets with a mixture of $20 \%$ A. karroo and $80 \%$ S. verticillata grass hay
(Table 5). Dietary mixture level and PEG 4000 supplementation did not affect $(P>0.05)$ daily $\mathrm{CP}$ intake of goats.

Similarly, goats fed a dietary mixture of $20 \%$ A. karroo leaf meal and $80 \% S$. verticillata grass hay had higher $(P<0.05)$ DM, OM, NDF and ADF intakes per metabolic weight than those on $50 \%$ A. karroo leaf meal and $50 \%$ S. verticillata grass hay (Table 4). Dry matter, OM, NDF and ADF intakes per goat metabolic weight were optimized at PEG 4000 supplementation levels of 20.34, 20.03, 20.56 and 20.56 g/goat/day, respectively, for goats on a mixture of $20 \%$ A. karroo leaf meal and $80 \% \mathrm{~S}$. verticillata grass hay (Table 5). Dietary mixture level and PEG 4000 supplementation did not affect $(P>0.05)$ daily CP intake per metabolic weight of goats.

Polyethylene glycol 4000 supplementation had no effect $(P>0.05)$ on the apparent digestibility of all nutrients. The dietary inclusion level of $A$. karroo leaf meal at $20 \%$ improved $(P<0.05)$ DM, OM, CP, NDF and ADF digestibility of goats. Crude protein digestibility was optimized at a PEG 4000 supplementation level of $15.78 \mathrm{~g} / \mathrm{goat} /$ day (Table 5 ).

Table 4 Effects of polyethylene glycol 4000 supplementation and Acacia karroo leaf meal inclusion on diet intake, digestibility, body weight change and blood serum chemistry of yearling male indigenous Pedi goats fed a Setaria verticillata grass hay-based diet

\begin{tabular}{|c|c|c|c|c|c|c|c|c|c|c|}
\hline & \multicolumn{3}{|c|}{ Peg level (g/goat/day) } & \multirow[t]{2}{*}{ SE } & \multicolumn{2}{|c|}{${ }^{\mathrm{c}}$ Diet level } & \multirow[t]{2}{*}{ SE } & \multicolumn{3}{|l|}{$P$ Value } \\
\hline & 0 & 23 & 30 & & 20 & 50 & & Peg & Diet & Peg ${ }^{c}$ Diet \\
\hline \multicolumn{11}{|l|}{ Intake (g/goat/day) } \\
\hline $\mathrm{DM}$ & 543 & 580 & 590 & 70.40 & $652^{\mathrm{a}}$ & $490^{\mathrm{b}}$ & 57.48 & 0.8389 & 0.0338 & 0.0418 \\
\hline OM & 498 & 531 & 541 & 64.48 & $596^{\mathrm{a}}$ & $450^{\mathrm{b}}$ & 52.65 & 0.8398 & 0.0350 & 0.0417 \\
\hline $\mathrm{CP}$ & 52 & 54 & 56 & 6.72 & 58 & 51 & 5.49 & 0.9069 & 0.2770 & 0.0418 \\
\hline $\mathrm{NDF}$ & 344 & 381 & 383 & 45.97 & $455^{\mathrm{a}}$ & $284^{\mathrm{b}}$ & 37.53 & 0.7217 & 0.0022 & 0.0439 \\
\hline $\mathrm{ADF}$ & 239 & 262 & 264 & 31.60 & $306^{\mathrm{a}}$ & $204^{\mathrm{b}}$ & 25.80 & 0.7616 & 0.0054 & 0.0426 \\
\hline \multicolumn{11}{|l|}{ Intake $\left(\mathrm{g} / \mathrm{kg} \mathrm{W}^{-0.75}\right)$} \\
\hline $\mathrm{DM}$ & 49 & 55 & 56 & 4.888 & $61^{\mathrm{a}}$ & $45^{\mathrm{b}}$ & 3.991 & 0.5742 & 0.0139 & 0.1021 \\
\hline $\mathrm{OM}$ & 45 & 51 & 51 & 4.471 & $56^{\mathrm{a}}$ & $41^{\mathrm{b}}$ & 3.651 & 0.5749 & 0.0147 & 0.1037 \\
\hline $\mathrm{CP}$ & 4.7 & 5.2 & 5.3 & 0.462 & 5.5 & 4.7 & 0.378 & 0.6537 & 0.1654 & 0.1060 \\
\hline $\mathrm{NDF}$ & 31 & 36 & 36 & 3.246 & $43^{\mathrm{a}}$ & $26^{\mathrm{b}}$ & 2.651 & 0.4912 & 0.0008 & 0.1033 \\
\hline $\mathrm{ADF}$ & 21 & 25 & 25 & 2.214 & $29^{\mathrm{a}}$ & $19^{\mathrm{b}}$ & 1.807 & 0.5057 & 0.0019 & 0.0994 \\
\hline \multicolumn{11}{|l|}{ Digestibility (decimal) } \\
\hline $\mathrm{DM}$ & 0.71 & 0.72 & 0.73 & 0.007 & $0.74^{\mathrm{a}}$ & $0.71^{\mathrm{b}}$ & 0.005 & 0.1002 & 0.0024 & 0.1491 \\
\hline $\mathrm{OM}$ & 0.73 & 0.72 & 0.74 & 0.008 & $0.75^{\mathrm{a}}$ & $0.71^{\mathrm{b}}$ & 0.007 & 0.4066 & 0.0056 & 0.0604 \\
\hline $\mathrm{CP}$ & 0.62 & 0.63 & 0.64 & 0.016 & $0.68^{\mathrm{a}}$ & $0.59^{\mathrm{b}}$ & 0.013 & 0.7355 & 0.0004 & 0.0902 \\
\hline NDF & 0.64 & 0.66 & 0.67 & 0.009 & $0.71^{\mathrm{a}}$ & $0.60^{\mathrm{b}}$ & 0.007 & 0.1104 & $<.0001$ & 0.3816 \\
\hline $\mathrm{ADF}$ & 0.63 & 0.65 & 0.69 & 0.030 & $0.70^{\mathrm{a}}$ & $0.62^{\mathrm{b}}$ & 0.025 & 0.3464 & 0.0365 & 0.7346 \\
\hline Initial BW (kg) & 23.8 & 22.5 & 22.2 & 1.095 & 22.7 & 23.0 & 0.894 & 0.5660 & 0.7769 & 0.0666 \\
\hline Final BW (kg) & 24.1 & 22.8 & 23.0 & 1.150 & 22.9 & 23.7 & 0.939 & 0.6765 & 0.5800 & 0.0760 \\
\hline Gain (g/goat/day) & 44.8 & 74.6 & 72.1 & 18.00 & $36.1^{\mathrm{b}}$ & $91.6^{\mathrm{a}}$ & 14.69 & 0.4534 & 0.0203 & 0.3242 \\
\hline Urea $(\mathrm{mmol} / \mathrm{L})$ & 2.9 & 3.0 & 2.5 & 0.318 & 2.7 & 2.8 & 0.260 & 0.5131 & 0.6589 & 0.5515 \\
\hline Glucose $(\mathrm{mmol} / \mathrm{L})$ & 2.7 & 2.8 & 2.9 & 0.058 & 2.8 & 2.8 & 0.260 & 0.1744 & 0.6308 & 0.5023 \\
\hline
\end{tabular}

$S E$ standard error, $B W$ body weight

a, b Means with different superscripts within rows are significantly different $(P<0.05)$; SE: Standard error; BW: Body weight

${ }^{\mathrm{c}}$ Diet level refers to the percentage of inclusion of Acacia karroo leaf meal 
Table 5 PEG 4000 supplementation levels for optimal dietary intakes in indigenous Pedi goats fed diets with a mixture of $20 \%$ Acacia karroo leaf meal and $80 \%$ Setaria verticillata grass hay

\begin{tabular}{|c|c|c|c|c|}
\hline Variable & Formula & $\begin{array}{l}\text { PEG Supplementation } \\
\text { level }\end{array}$ & Optimal Y-Level & $r^{2}$ \\
\hline \multicolumn{5}{|c|}{ Intake (g/goat/day) } \\
\hline DM & $Y=495+28.482 \times+-0.726 \times^{2}$ & 19.62 & 774.75 & 0.95 \\
\hline $\mathrm{OM}$ & $Y=452.99+26.058 \times+-0.664 \times^{2}$ & 19.62 & 708.67 & 0.94 \\
\hline $\mathrm{NDF}$ & $Y=346+19.884 \times+-0.507 \times{ }^{2}$ & 19.61 & 540.95 & 0.92 \\
\hline $\mathrm{ADF}$ & $Y=233+13.555 \times+-0.347 \times{ }^{2}$ & 19.53 & 365.36 & 0.91 \\
\hline \multicolumn{5}{|c|}{ Intake $\left(\mathrm{g} / \mathrm{kgW}^{-0.75}\right)$} \\
\hline DM & $Y=49+2.237 \times+-0.055 \times^{2}$ & 20.34 & 71.75 & 0.85 \\
\hline $\mathrm{OM}$ & $Y=45+2.083 \times+-0.052 \times{ }^{2}$ & 20.03 & 65.86 & 0.89 \\
\hline $\mathrm{NDF}$ & $Y=34+1.480 \times+-0.036 \times{ }^{2}$ & 20.56 & 49.21 & 0.84 \\
\hline $\mathrm{ADF}$ & $Y=23+0.987 \times+-0.024 \times^{2}$ & 20.56 & 33.14 & 0.78 \\
\hline \multicolumn{5}{|c|}{ Digestibility (decimal) } \\
\hline $\mathrm{CP}$ & $Y=0.660+0.0082 \times+-0.0002 \times^{2}$ & 15.78 & 0.72 & 0.93 \\
\hline
\end{tabular}

$r^{2}$ coefficient of determination

Dietary mixture level and PEG 4000 supplementation had no effect $(P>0.05)$ on final weights of Pedi goats. Similar results were observed for blood urea and glucose concentrations of yearling male Pedi goats. However, daily body weight gain was higher $(P<0.05)$ in goats fed $50 \%$ A. karroo leaf meal than those on $20 \%$ inclusion level.

\section{Discussion}

A. karroo leaf meal contained $127 \mathrm{~g} \mathrm{CP}$ per kg DM, indicating that it has potential as a browse source for goats. Leaves of fodder trees have been used as supplements to grass hay-based diets, especially during the critical dry periods of the year (Tshabalala et al. 2013). These tree fodders have been incorporated into the rations of ruminants as substitutes for more expensive processed protein sources (Norton 1994). The condensed tannin contents of the dietary mixture of A. karroo leaf meal and $S$. verticillata hay varied from $4.0 \mathrm{~g} / \mathrm{kg} \mathrm{DM}$ for diet containing a $20 \% \mathrm{~A}$. karroo inclusion level to $10.0 \mathrm{~g} / \mathrm{kg} \mathrm{DM}$ for the diet containing 50\% A. karroo. Dube et al. (2001) and Mokoboki et al. (2005) indicated that $A$. karroo leaves contain high levels of extracted condensed tannins (CT), ranging from 55 to $110 \mathrm{~g} / \mathrm{kg} \mathrm{DM}$.

In the present study, PEG by diet interaction increased the intake of all nutrients. Dry matter, OM, NDF and ADF intakes were optimized at PEG 4000 supplementation levels of 19.62, $19.62,19.61$ and $19.53 \mathrm{~g} /$ goat, respectively. This finding is similar to those of Yisehak et al. (2013) who reported significant interaction effect of diet and PEG on DM, OM, CP, NDF and ADF. The considerable improvement in the intake of all studied nutrients after the incorporation of PEG reveals the positive impact of PEG when added to tanniniferous diet
(Frutos et al. 2004). According to Makkar (2003), intake of tanniniferous diet can be increased by using compound that has high affinity for tannins like PEG. Silanikove et al. (1996a, b) and Titus et al. (2001) also reported that PEG supplementation increased intake of tanniniferous browse foliage. The incorporation of PEG in the diet breaks tannin-fibre complexes, which consequently allows their digestion by microbial enzymes (Frutos et al. 2004; Yisehak et al. 2013). Inactivation of tannins through PEG increased availability of nutrients (protein, carbohydrates and minerals) to the animal and decreased microbial inhibition leading to higher animal performance (Makkar 2003).

Polyethylene glycol supplementation had no effect on the apparent digestibility of nutrients in the present study. Silanikove et al. (1996a, b) found that goats fed high-tannin Pistacia lentiscus with PEG (10 g/day) had negative CP digestibility. Similarly, Motubatse et al. (2008) reported that PEG 4000 supplementation did not affect NDF and ADF digestibility in Pedi goats fed Acacia nilotica leaf meal. Contrary to this result, other authors have reported significant improvement in the apparent digestibility of nutrients (OM and CP) with PEG supplementation (Barry et al. 1986; Ben Salem et al. 2005; Yisehak et al. 2013). The effect of PEG depends on the level of protein in the diet. The higher the level of protein in a diet, the lower is the effect of PEG (Austin et al. 1989; Makkar and Becker 1996; Alonso-Diaz et al. 2010). This may account for the reduced nutrient digestibility observed for goats on $50 \%$ A. karroo leaf meal.

The final body weight of goats was not improved with dietary mixture level and PEG supplementation. These findings are similar to those of Ben Salem et al. (2005), who reported non-significant effects in the final body weight of goats fed tannin-rich oak (Quercus coccifera L.) and 
supplemented with PEG 4000. In contrast, Motubatse et al. (2008) reported improved final body weights in Pedi goats fed different levels of A. nilotica leaf meal and supplemented with PEG 4000. The difference in responses may be related to differences in the chemical composition of the browse species (Madibela et al. 2006). It should be noted that discrepancies in body weight change may also be due to changes in rumen fill, which might not represent changes occurring in the body tissues (Motubatse et al. 2008). A. karroo leaf meal at 50\% improved daily body weight gain of goats. This observation may be due to higher protein content in the diet. Improvement in weight gain of goats on tanniniferous diets have been document (Solaiman et al. 2010; Gwanzura et al. 2011; Brown et al. 2017). Rumen microorganisms are able to metabolize tannins or remain active in a high tannin environment and overcome their detrimental effects, which in turn improves animal performance (Makkar 2003).

There was no consistent effect of PEG 4000 supplementation and dietary treatments on serum urea and glucose concentration of the goats. These findings are similar to the report of Ben Salem et al. (2005). Serum glucose was within the normal range of 2.78-4.16 mmol/1 reported for healthy goats (Kaneko 1997). Serum urea level was below the normal established range of 3.5-10.7 mmol/1 (Sirois 1995). The reason for depressed serum urea in the present experiment merits further study.

In conclusion, A. karroo leaf meal has potential as a protein feed for ruminants. However, it also contained relatively high amounts of condensed tannins, which can deter intake and digestion in goats. The negative effects of tannins on nutrient intake could be reversed by supplementing tannin-binding agents such as PEG. Supplementation level of about $20 \mathrm{~g}$ of PEG 4000 per goat per day optimized DM, OM, NDF and $\mathrm{ADF}$ intakes. This level of supplementation is recommended if intake is the parameter of interest. Crude protein digestibility was optimized at a PEG 4000 supplementation level of $15.78 \mathrm{~g}$ per goat per day. This supplementation level for optimal CP digestibility is lower than the $20 \%$ for intake. Thus, the supplementation level for optimal productivity depended on the production parameters of interest. This has implications on supplementation recommendations. Dietary inclusion level of A. karroo at $50 \%$ did not improve intake and digestibility of the animals. It is possible that PEG 4000 was not enough to have effect on the performance of the goats. Similarly, the condensed tannins may have exerted adverse effects on the performance of the goats. All this requires further studies.

Acknowledgements The authors acknowledge financial support from the National Research Foundation.

\section{Compliance with ethical standards}

Ethical approval All procedures involving animals were in accordance with the ethical standards of the Animal Research Ethics Committee of the University of Limpopo, South Africa.
Conflict of interest The authors declare that they have no conflict of interest.

Open Access This article is distributed under the terms of the Creative Commons Attribution 4.0 International License (http:// creativecommons.org/licenses/by/4.0/), which permits unrestricted use, distribution, and reproduction in any medium, provided you give appropriate credit to the original author(s) and the source, provide a link to the Creative Commons license, and indicate if changes were made.

\section{References}

Alonso-Diaz, M.A., Torres-Acosta, J.F.J., Sandoval-Castro, C.A. and Hoste, H., 2010. Tannins in tropical tree fodders fed to small ruminants: A friendly foe? Small Ruminant Research, 89, 164-173.

AOAC, 2005. Official methods of analysis. Association of Analytical Chemists, 18th edition. Washington, DC.

Austin, P.J., Suchar, L.A., Robbins, C.T. and Hagerman, A.E., 1989. Tannins-binding proteins in saliva of deer and their absence in saliva of sheep and cattle. Journal of Chemical Ecology, 15, 1335-1347.

Barry, T.N., Manley, T.R. and Duncan, S.J., 1986 The role of condensed tannins in the nutritional value of Lotus pedunculatus for sheep. Site of carbohydrate and protein digestion as influenced by dietary reactive tannin concentration. British Journal of Nutrition, 55:123-137.

Barry, T.N., McNeill, D.M. and McNabb, W.C., 2001. Plant secondary compounds: their impact on forage nutritive value and upon animal production. In: Proceedings of the XIX International Congress, 445452.

Belachew, Z., Yisehak, K., Taye, T. and Janssens, G.P.J., 2013. Chemical composition and in sacco ruminal degradation of tropical trees rich in condensed tannins. Czech Journal of Animal Science, 58,176192.

Ben Salem, H., Ben Salem, I. and Ben-Said, M.S., 2005. Effect of the level and frequency of PEG supply on intake, digestion, biochemical and clinical parameters by goats given Kermes oak (Quercus Coccifera L.)-based diets. Small Ruminant Research, 56, 127-137.

Bhatta, R., Shinde, A.K., Vaithiyanathan, S., Sankhyan, S.K. and Verma, D.L., 2002. Effect of polyethylene glycol-6000 on nutrient intake, digestion and growth of kids browsing Prosopis cineraria. Animal Feed Science and Technology, 101, 45-54.

Brown, D., Ng'ambi, J.W. and Norris, D., 2016. Voluntary intake and palatability indices of Pedi goats fed different levels of Acacia karroo leaf meal by cafeteria method. Indian Journal of Animal Research, 50, 41-47.

Brown, D., Ng'ambi, J.W. and Norris, D., 2017. Effect of tanniniferous Acacia karroo leaf meal inclusion level on feed intake, digestibility and live weight gain of goats fed a Setaria verticillata grass haybased diet. Journal of Applied Animal Research, DOI: 10.1080/ 09712119.2017.1289939.

Christopher, D.L., 2012. Nutritionally related strategies for organic goat production. Small Ruminant Research, 39, 1-10.

Decandia, M., Sitzia, M., Cabiddu, A., Kababya, D. and Molle, G., 2000. The use of polyethylene glycol to reduce the anti-nutritional effects of tannins in goats fed woody species. Small Ruminant Research, 38, 157-164.

Domestic Animal Genetic Resources Information System (DAGRIS). 2007. In: Rege, J.E.O., Hanotte, O., Mamo, Y., Asrat, B. and Dessie, T. (eds), International Livestock Research Institute, Addis Ababa, Ethiopia.

Dube, J.S., 2000. The use of Acacia karroo and Acacia nilotica leaves as dry season supplementary feeds for livestock. In: Holness, D.H. (Ed.), Strategies for Dry Season Feeding of Animals in Central 
and Southern Africa; Proceedings of a Joint Zimbabwe Society for Animal Production and Food and Agriculture Organisation Subregional Office for Southern and East Africa, Workshop Harare, Zimbabwe, 1999, 121-127.

Dube, J.S., Reed, J.D. and Ndlovu, L.R., 2001. Proanthocyanidins and other phenolics in Acacia leave of Southern Africa. Animal Feed Science and Technology, 91, 59-67.

Frutos, P., Hervás, G., Giráldez, F.J. and Mantecó, A.R., 2004. Review. Tannins and ruminant nutrition. Spanish Journal of Agricultural Research, 2, 191-202.

Gwanzura, T., Ngambi, J.W. and Norris, D., 2011. Effects of selected species and forage sorghum hay grown in Limpopo province on voluntary intake and relative palatability indices of Pedi goats. Asian Journal of Animal and Veterinary Advances, 12, 1249-1255.

Kaitho, R.J., Umunna, N.N., Nsahlai, I.V., Tamminga, S., Van Bruchem, J., Hanson, J. and Van DeWouw, M., 1996. Palatability of multipurpose tree species: Effect of species and length of study on intake and relative palatability by sheep. Agroforestry Systems, 33, 249-261.

Kaneko, J.J., 1997. Clinical Biochemistry of Domestic Animals. 5th edition. Academic Press Inc., New York, U.S.A., 885-905.

Madibela, O.R., Seitshiro, O. and Mochankana, M.E., 2006. Deactivation effects of polyethylene glycol (PEG) on in vitro dry matter digestibility of Colophospermum mopane and Acacia browse trees in Botswana. Pakistan Journal of Nutrition, 5, 343-347.

Makkar, H.P.S., 2003. Effects and fate of tannins in ruminant animals, adaptation to tannins, and strategies to overcome detrimental effects of feeding tannin-rich feeds. Small Ruminant Research, 49, 241256

Makkar, H.P.S. and Becker, K., 1996. A bioassay for tannins. In: Polyphenols Communications, vol. 96. Proceedings of the XVIIIth International Conference on Polyphenols, Bordeaux, July 15-18, 197-198.

Mapiye, C., Chimonyo, M., Marufu, M.C. and Dzama, K., 2011. Utility of Acacia karroo for beef production in Southern African smallholder farming systems. Animal Feed Science and Technology, 164, 135-146.

Matlebyane, M.M., Ng'ambi, J.W. and Aregheore, E.M., 2010. Indigenous knowledge (IK) ranking of available browse and grass species and some shrubs used in medicinal and ethno-veterinary practices in ruminant livestock production in Limpopo province, South Africa. Livestock Research for Rural Development, 22, 3.

Mokoboki, H.K., Ndlovu, L.R., Ng'ambi, J.W., Malatje, M.M. and Nikolova, R.V., 2005. Nutritive value of Acacia tree foliage growing in the Limpopo Province of South Africa. South African Journal of Animal Science, 35, 221-228.

Motubatse, M.R., Ngambi, J.W., Norris, D. and Malatje, M.M., 2008. Effect of polyethylene glycol 4000 supplementation on the performance of indigenous Pedi goats fed different levels of Acacia nilotica leaf meal and ad libitum Buffalo grass hay. Tropical Animal Health and Production, 40, 229-238.

Ngambi, J.W., Alabi, O.J., and Norris, D., 2013. Role of goats in food security, poverty alleviation and prosperity with special reference to Sub-Saharan Africa: A review. Indian Journal of Animal Research, 47, 1-9.

Norton, B.W., 1994. Tree Legumes as dietary supplements for ruminants, pp: 192-201. In Gutteridge R. C and H. M. Shelton: Forage Tree Legumes in Tropical Agriculture, CAB International, Wallingford.
Nsahlai, I.V., Fon, F.N. and Basha, N.A.D., 2011. The effect of tannin with and without polyethylene glycol on in vitro gas production and microbial enzyme activity. South African Journal of Animal Science, 41, 337-344.

Olafadehan, O.A., Adewumi, M.K. and Okunade, S.A., 2014. Effects of feeding tannin-containing forage in varying proportion with concentrate on the voluntary intake, haematological and biochemical indices of goats. Trakia Journal of Sciences, 1, 73-81.

Porter, L.J., Hristich, L.N. and Chan, B.G., 1986. The conversion of procyanidins and prodelphinidins to cyanidins and delphinidins. Phytochemistry, 25, 223-230.

Sarwatt, S.V., Laswai, G.H. and Ubwe, R., 2003. Evaluation of the potential of Trichanthera gigantea as a source of nutrients for rabbit diets under small-holder production system in Tanzania. Livestock Research for Rural Development. http://www.cipav.org.co/lrrd/ lrrd15/11/sarw1511.htm.

SAS, 2010. User's Guide: Statistics. SAS Institute Inc., Cary, MC., USA.

Silanikove, N., Gilboa, N., Nir, I., Perevolotsky, A. and Nitzan, Z. 1996a. Effect of a daily supplementation of polyethylene glycol on intake and digestion of tannin-containing leaves (Quercus calliprinos, Pistacia lentiscus and Ceratonia siliqua) by goats. Journal of Agricultural and Food Chemistry, 42, 199-205.

Silanikove, N., Gilboa, N., Perevolotsky, Z. and Nitsan, Z., 1996b. Goats fed tannin-containing leaves do not exhibit toxic syndromes. Small Ruminant Research, 21, 195-201.

Singh, B., Sahoo, A. and Sharma, R., 2005. Effect of polyethylene glycol on gas production parameters and nitrogen disappearance of some tree forages. Animal Feed Science and Technology, 123, 351-364.

Sirois, M., 1995. Veterinary Clinical Laboratory Procedure. Mosby Year Book, Inc. St Louis, Missouri.

Snyman, M.A., 2014. South African goat breeds: Indigenous veld goat. Grootfontein Agricultural Development Institute, Middelburg.

Solaiman, S., Thomas, J., Dupre, Y., Min, B.R., Gurung, N., Terrill, T.H. and Haenlein, G.F.W., 2010. Effect of feeding sericea lespedeza (Lespedeza cuneata) on growth performance, blood metabolites, and carcass characteristics of Kiko crossbred male kids. Small Ruminant Research, 93, 149-156.

Titus, C.H., Provenza, F.D., Perelovotsky, A., Silaniokove, N. and Rogosic, J., 2001. Supplemental polyethylene glycol influences preferences of goats browsing blackbrush. Journal of Range Management, 54,161-165.

Tshabalala, T., Sikosana, J.L.N. and Chivandi, E., 2013. Nutrient intake, digestibility and nitrogen retention in indigenous goats fed on Acacia nilotica fruits treated for condensed tannins. South African Journal of Animal Science, 43, 457-463.

Valley, H., Gowelock, A.H. and Bell, M., 1980. Determination of serum urea using diacetyl monoxime method. In: Practical Clinical Biochemistry, $5^{\text {th }}$ edn. William Heinemann Medical Books Ltd., London.

Van Soest, P., 1994. Nutritional ecology of the ruminant. $2^{\text {nd }}$ Edition. Cornell University Press, London.

Water, P.G and Mole, S., 1994. Analysis of phenolics plant metabolies. Blackwell, Oxford, UK.

Yisehak, K., De-Boever, J. and Janssens, G.P.J., 2013. The effect of supplementing leaves of four tannin-rich plant species with polyethylene glycol on digestibility and zootechnical performance of zebu bulls (Bos indicus). Journal of Animal Physiology and Animal Nutrition, 98, 431-438. 